\title{
Campylosteira Fieber, 1844 (Hemiptera: Tingidae) a newly recorded member of the Bulgarian lace bug fauna
}

\author{
Nikolay Simov', Toshko Ljubomirov²
}

1 National Museum of Natural History, Bulgarian Academy of Sciences, 1 Tsar Osvoboditel Blvd, 1000 Sofia, Bulgaria, e-mail: myrmedobia@gmail.com

2 Institute of Biodiversity and Ecosystem Research, Bulgarian Academy of Sciences, 2 Gagarin Street, 1113 Sofia, Bulgaria, e-mail: toshkoljubomirov@gmail.com

\begin{abstract}
We report the first record for Bulgaria of Campylosteira orientalis Horváth, 1881 and the genus Campylosteira, on the whole, along with data of the habitats and the true bug assemblage in the studied locality.
\end{abstract}

Keywords: Bulgaria, Heteroptera, Tingidae, Western Pontic steppes

\section{Introduction}

Currently, the Bulgarian lace bug fauna comprises 18 genera with 67 species (Josifov, 1986, 1990; Péricart \& Golub, 1996; Simov \& Pencheva, 2007; Dobreva et al., 2013). In April and May 2018, a big series of an unknown very small lace bug was collected from three localities on the Bulgarian Black Sea coast by the second author. The specimens were identified by the first author as species of Campylosteira Fieber, 1844. In this paper, we present data about the first record of this lace bug genus in Bulgaria.

\section{Material and methods}

The material was collected using pitfall traps and colour pan traps (Fig. 1) in the course of studying the insect communities in north-eastern Bulgaria, close to Balchik Town. Three closely situated localities in the studied area were visited once every month from April to September 2018. The typical habitat in the studied localities was E1.2D1 Western Pontic steppes (Fig. 2) according EUNIS Habitat classification. The habitat has been classified as endangered in Bulgaria

Received: 22 May 2020 • Editor: Mario Langourov and very important for the preservation of many rare, endangered and protected plants and animals (Tzonev et al., 2015; Abadjiev \& Beshkov, 2007). It covers restricted areas in north-eastern Bulgaria and was subjected to various long-lasting negative impacts: golf playground construction, holiday complexes, motor racing, wind electric power parks (Abadjiev \& Beshkov, 2007; Tzonev et al., 2015).

The material has been deposited in the collection of the National Museum of Natural History, Sofia (NMNHS).

\section{Results and discussion}

Campylosteira orientalis Horváth, 1881 (Fig. 3) material examined: Bulgaria: Black Sea Coast, SW Balchik Town, $43.396098^{\circ} \mathrm{N} ; 28.106186^{\circ} \mathrm{E} ; 210 \mathrm{~m}$

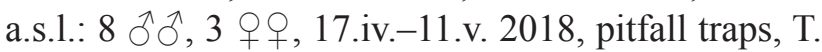

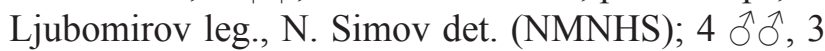
우, 11.v.-10.vi. 2018, pitfall traps, T. Ljubomirov leg., N. Simov det. (NMNHS). The range of C. orientalis includes territories of south-eastern Europe and Caucasus: Albania, Croatia, Greece, Hungary, Italy, Montenegro, Romania, Russia (ST: N Caucasus), Slo- 
Nikolay Simov, Toshko Ljubomirov

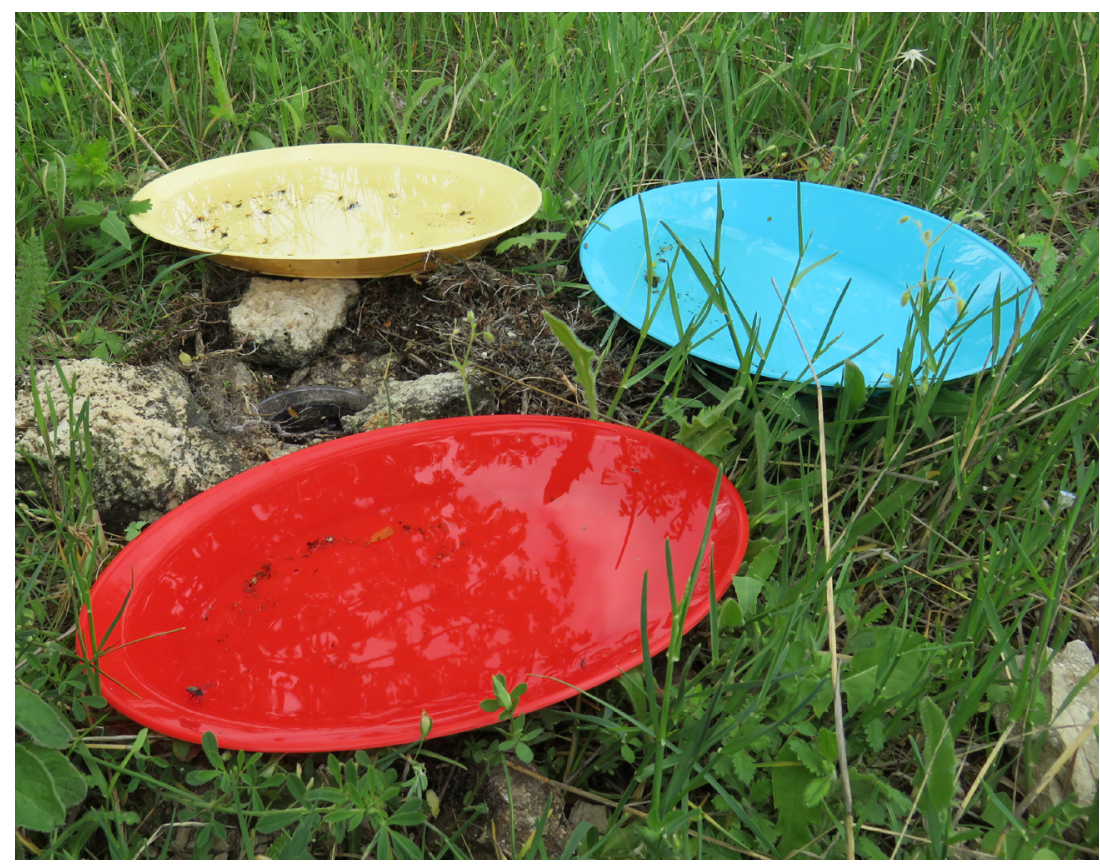

$\leftarrow$ Fig. 1. Pitfall and coloured pan traps used in this study.

$\downarrow$ Fig. 2. Western Pontic steppes (EUNIS habitat type E1.2D1) in the studied area close to Balchik Town, northern Black Sea Coast.

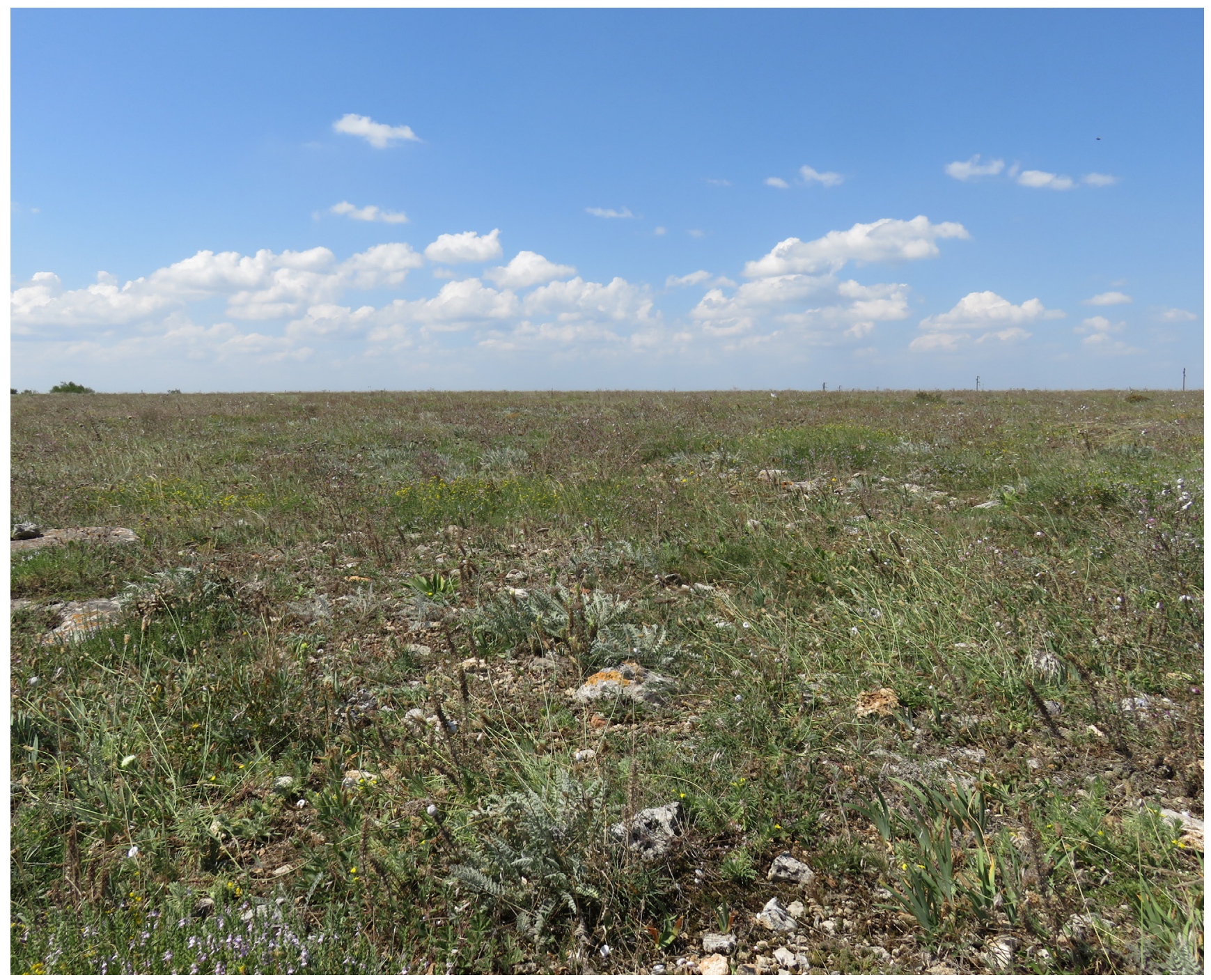




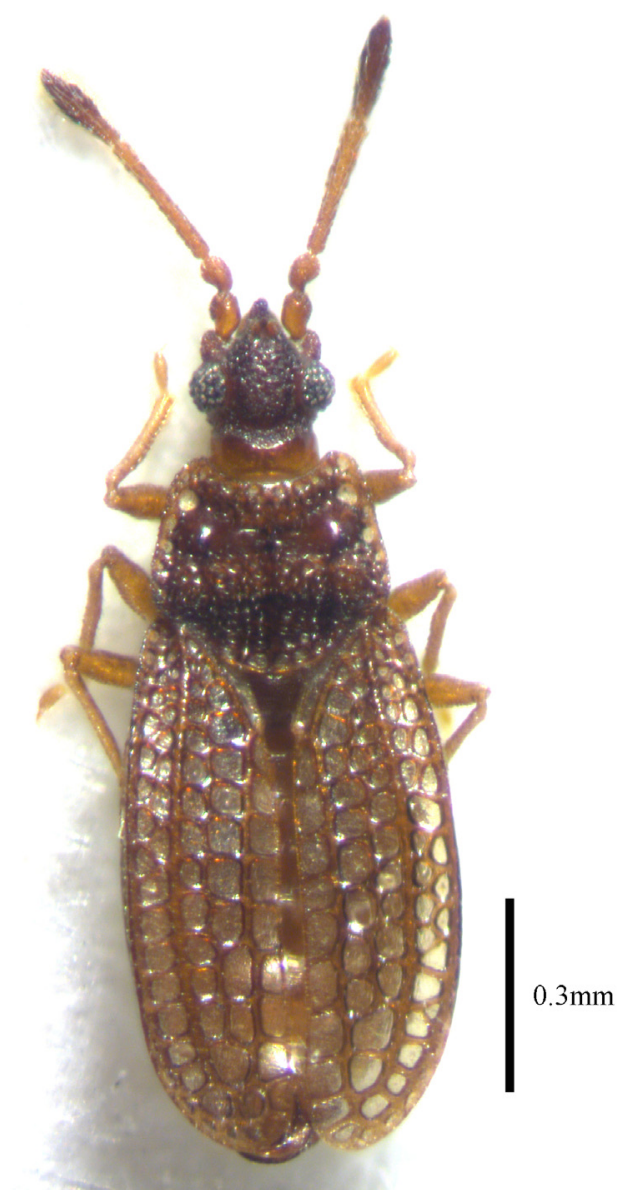

Fig. 3. Campylosteira orientalis Horváth, 1881 - a male collected in April-May 2018 in Bulgaria.

venia, Ukraine, Azerbaijan, Armenia, Turkey (Péricart \& Golub, 1996; Protić, 2004). Overall, this is the first record of $C$. orientalis and the genus Campylosteira in Bulgaria. The finding is not a surprise. The closest published localities of the species are in the neighbouring Balkan countries Romania, Montenegro, Greece, and Albania (Péricart \& Golub 1996, Protić, 2004). Similar habitat preferences of this and other species of the genus were published for the territories of England, Ukraine and Hungary, and namely steppe and dry calcareous grassland and Pannonic steppes (Putshkov, 1974; Péricart, 1983; Redei et al., 2003; Alexander, 2008; Glime 2017).

Other species of true bugs recorded during our study from the same habitats were:

Tingidae

- Acalypta marginata (Wolff, 1804) - material examined: Bulgaria: Black Sea Coast, SW Balchik Town, $43.396098^{\circ} \mathrm{N} ; 28.106186^{\circ} \mathrm{E} ; 210 \mathrm{~m}$ a.s.1.: 1 ○, 1 + , 17.iv.-11.v. 2018, pitfall traps, T.

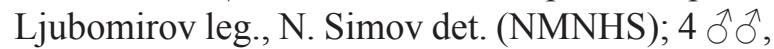
3 우, 11.v.-10.vi. 2018, pitfall traps, T. Ljubomirov leg., N. Simov det. (NMNHS);

- Catoplatus carthusianus (Goeze, 1778) - material examined: Bulgaria: Black Sea Coast, SW Balchik Town, $43.396098^{\circ} \mathrm{N} ; 28.106186^{\circ} \mathrm{E} ; 210 \mathrm{~m}$ a.s.l.: 1 9, 17.iv.-11.v. 2018, pan traps, T. Ljubomirov leg., N. Simov det. (NMNHS);

Rhyparochromidae

- Aellopus atratus (Goeze, 1778) - material examined: Bulgaria: Black Sea Coast, SW Balchik Town, $43.396098^{\circ} \mathrm{N} ; 28.106186^{\circ} \mathrm{E} ; 210 \mathrm{~m}$ a.s.l.: 1 9, 11.v.-10.vi. 2018, pitfall traps, T. Ljubomirov leg., N. Simov det. (NMNHS);

- Emblethis angustus Montandon, 1890 - material examined: Bulgaria: Black Sea Coast, SW Balchik Town, $43.396098^{\circ} \mathrm{N} ; 28.106186^{\circ} \mathrm{E} ; 210 \mathrm{~m}$ a.s.l.: 2

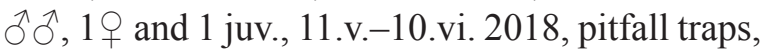
T. Ljubomirov leg., N. Simov det. (NMNHS);

- Plinthisus (s.str.) longicollis Fieber, 1861 - material examined: Bulgaria: Black Sea Coast, SW Balchik Town, $43.396098^{\circ} \mathrm{N} ; 28.106186^{\circ} \mathrm{E} ; 210$ $\mathrm{m}$ a.s.1.: 1 q, 11.v.-10.vi. 2018, pitfall traps, T. Ljubomirov leg., N. Simov det. (NMNHS);

- Tropistethus fasciatus Ferrari, 1874 - material examined: Bulgaria: Black Sea Coast, SW Balchik Town, $43.396098^{\circ} \mathrm{N} ; 28.106186^{\circ} \mathrm{E} ; 210 \mathrm{~m}$ a.s.l.: 1 Oे, 11.v.-10.vi. 2018, pitfall traps, T. Ljubomirov leg., N. Simov det. (NMNHS);

Scutelleridae

- Odontoscelis (s.str.) fuliginosa (Linnaeus, 1761) - material examined: Bulgaria: Black Sea Coast, SW Balchik Town, 43.396098 ${ }^{\circ} \mathrm{N} ; 28.106186^{\circ} \mathrm{E}$; $210 \mathrm{~m}$ a.s.1.: $3{ }^{\widehat{\lambda}} \mathrm{O}^{\lambda}$, 17.iv.-11.v. 2018, pitfall traps, T. Ljubomirov leg., N. Simov det. (NMNHS).

This species composition correspond well with the published for the localities of $C$. orientalis in Hungary (Redei et al., 2003, 2004). Campylosteira orientalis, A. marginata, E. angustus could be assigned to the typical ground-living species indicator complex associated with EUNIS habitat type E 1.2 Perennial calcareous grassland and basic steppes (Redei et al., 2003, 2004; present study).

The use of suction trapping with handhold leaf blower (vacuum combo), pitfalls and also sifting litter would be a successful attempt for the search of the same or other Campylosteira species in different Bulgarian regions with suitable habitats (Tzonev et al. 2015) in the future. 


\section{Acknowledgements}

We thank Victor Golub for his valuable comments on the early version of the manuscript.

\section{References}

Abadjiev S., Beshkov S. 2007 Prime Butterfly Areas in Bulgaria. Pensoft Publishers, Sofia-Moscow, $222 \mathrm{pp}$.

Alexander K.N. 2008 The Land and Freshwater Bugs (Hemiptera) of Cornwall and the Isles of Scilly. CISFBR \& ERCCIS Occasional Publication No. 2, $155 \mathrm{pp}$.

Dobreva M., Simov N., Georgiev G., Mirchev P., Georgieva M. 2013 First Record of Corythucha arcuata (Say) (Heteroptera: Tingidae) on Balkan Peninsula. Acta zoologica bulgarica 65 (3): 409412.

Glime J.M. 2017 Terrestrial Insects: Hemimetabola Hemiptera (Heteroptera). Chapter 12-6. In: Glime, J.M. Bryophyte Ecology. Volume 2. Interactions. Ebook sponsored by Michigan Technological University and the International Association of Bryologists. eBook last updated 21 April 2017; http:// digitalcommons.mtu.edu/bryophyte-ecology $2 /$

Josifov M. 1986 Verzeichnis der von der Balkanhalbinsel bekannten Heteropterenarten (Insecta, Heteroptera). Faunistische Abhandlungen Staatliches Museum für Tierkunde in Dresden 14 (6): 61-93.

Josifov M. 1990 On the appearance of the nearctic species Corytucha ciliata (Say, 1832) (Heteroptera, Tingidae) in Bulgaria. Acta zoologica bulgarica 39: 53-55. (In Bulgarian)

Péricart J. 1983 Hémiptères Tingidae euro-méditerranéens. Faune de France 69. Fédération Française des Sociétés de Sciences Naturelles, Paris, $618 \mathrm{pp}$.
Péricart J., Golub V.B. 1996 Superfamily Tingoidea Laporte, 1832. In: Aukema B., Rieger Ch. (eds) Catalogue of the Heteroptera of the Palaearctic Region. Vol. 2. Cimicomorpha I. The Netherlands Entomological Society, Amsterdam, 3-78.

Protic L. 2004 Additions and corrections to the Catalogue of the Heteroptera of the Palaearctic Region: Tingidae of the Balkan Peninsula. Acta Entomologica Slovenica 12: 229-238.

Putshkov V.G. 1974 Berytidae, Pyrrhocoridae, Piesmatidae, Aradidae and Tingidae. Fauna of the Ukraine 21 (4): 1-332. (In Ukrainian)

Rédei D., Gaál M., Hufnagel L. 2003 Spatial and temporal patterns of true bug assemblages extracted with Berlese funnels (Data to the knowledge on the ground-living Heteroptera of Hungary, No. 2). Applied Ecology and Environmental Research 1: 115-142.

Rédei D., Harmat B., Hufnagel L. 2004 Ecology of the Acalypta species occurring in Hungary (Insecta Heteroptera Tingidae) (Data to the knowledge on the ground-living Heteroptera of Hungary, No 3). Applied Ecology and Environmental Research 2 (2): 73-91.

Simov N., Pencheva A. 2007 Stephanitis rhododendri Horváth ,1905 (Heteroptera: Tingidae) - a new American pest on rhododendrons in Bulgaria. Rastenievŭdni nauki, Sofia 43: 483-485. (In Bulgarian)

Tzonev R., Roussakova V., Dimitrov M. 2015 Western-Pontic petrophytic steppes. In: Biserkov V., Gussev Ch. (eds) Red Data Book of the Republic of Bulgaria. Volume 3. Natural habitats. Bulgarian Academy of Sciences \& Ministry of Environment and Waters, Sofia, 148-150. 